must be research into the nature, timing and amount of deformation through which the rocks have passed, since it is only by making estimates of the strain impressed on the various units that their original relationships can be understood. Preliminary investigations (with the help of J. Watterson) suggest firstly that simple shear is perhaps the most important mechanism by which these rocks were deformed and secondly that $X: Z$ ratios in typical quartzo-feldspathic Nûk gneisses are of the order of 50:1 or more. Deformation of this type implies that there must have been a very considerable transport of material parallel to the main direction of elongation (Escher \& Watterson, in press). This suggests that in the Godthåbsfjord area there has been major subhorizontal movements in a SSW-NNE trending zone.

\title{
References
}

Andrews, J. R., Bridgwater, D., Gormsen, K., Gulson, B. L., Keto, L. \& Watterson. J. (in press): The Precambrian of South-East Greenland in Park, G. \& Tarney, J. (edit.). The Lewisian of Scotland and related rocks of Greenland. Proceedings of the 1971 symposium at Keele, England. University of Birmingham Press.

Escher, A., Escher, J. C. \& Watterson, J.: The reorientation of the Kângamiut dyke swarm, West Greenland, MS submitted to Can. J. Earth Sci.

Escher, A. \& Watterson, J.: Stretching fabrics, folds, and crustal shortening. (MS to be submitted to Tectonophysics).

McGregor, V. R. 1973: The early Precambrian gneisses of the Godthåb district, West Greenland. Phil. Trans R. Soc. Lond. A, 273, 343-358.

Pankhurst, R. J., Moorbath, S. \& McGregor, V. R.: A late (ca. 3000 m. y.) event in the geological evolution of the Godthaab district, West Greenland. MS submitted to Nature, Lond.

V.R.M., Atangmik,

3912 Sukkertoppen, Greenland.

\section{FIELD WORK ON THE PRECAMBRIAN BASEMENT IN THE BUKSEFJORDEN REGION, SOUTHERN WEST GREENLAND}

\section{Brian Chadwick and Kenneth Coe}

The summer of 1972 was the first of a five-season project in which geologists of the University of Exeter will map the 1:100 000 scale Buksefjorden sheet. A. D. Gibbs and M. R. Sharpe mapped the Qeqertarssuaq and Færingehavn areas while the authors made a reconnaissance of the entire map sheet in order to assess problems and establish sub-areas for mapping and research in forthcoming seasons. 
Previous reconnaissance work had been done by Berthelsen (1955), S $\varnothing$ rensen (1955), Noe-Nygaard \& Ramberg (1961) and Windley (1972). The north-western part of the sheet has been mapped by V. R. McGregor (1973; OIGL \& McGregor, 1971), and the writers acknowledge his great help in the field at the beginning of the season. McGregor recognised a unit of gneisses which he called Amitsoq, characterised by the inclusion of amphibolitic remnants of a dyke swarm, the Ameralik dykes. These were intruded by a group of granitic rocks which were subsequently deformed and metamorphosed and called Nûk gneisses by McGregor. This chronological framework has been substantiated by our field work but in detail the terminology and chronology of McGregor have been found to be inadequate. In this account the terms Amîtsoq, Ameralik, Malene and Nûk are used with McGregor's original meaning. It is hoped that a full discussion of this problem will be presented in some future publication.

\section{Rock units}

Amitsoq gneisses occur throughout the area but are variably affected by metamorphism, mobilisation and plutonic intrusion. Rocks least affected by later events lie in the north-west, around Narssaq but even there their initial affinities have been blurred. They are well banded, leucocratic, migmatitic, hornblendebiotite gneisses and commonly contain thin amphibolites older than the Ameralik dykes. In some parts, such as south Qilángârssuit and the east of Alangordlia and Sermilik, thicker amphibolite formations occur which may be relics of very old supracrustal rocks. In areas of granulite-facies metamorphism the Amitsoq gneisses are charnockitic.

Swarms of basic Ameralik dykes, locally possessing anorthositic inclusions, were injected into the older gneissses. Their occurrence is shown in fig. 4. Discordant relationships are locally preserved in the hinges of folds where the dykes cut thin lenses and sheets of amphibolite parallel with the gneiss banding. The dykes were intruded in at least two episodes and they appear to be associated with small masses of metadiorite.

Younger quartzo-feldspathic gneisses have been sub-divided into two lithological types. The first occurs in the inner part of Buksefjorden and to the south around Amitsuarssugssuaq where gneisses have been derived by mobilisation and differentiation from a pre-existing gneiss parent. The latter have been impoverished in mafic components and form banded, nebulitic, granodioritic gneisses with local stringers of agmatised amphibolites. They are intruded by thin sheets of grey, generally poorly-banded but foliated granodiorite with acid ptygma. These form the second lithological type and are the same as the Nûk gneisses of McGregor. Thin sheets of these rocks also intrude the Amitsoq gneisses and the Malene supracrustal amphibolites and the anorthosites described below.

Amphibolite formations which have been called the Malene supracrustals by McGregor occur throughout the area. Their lithology is variable, notably in the 
west on Qilángârssuit island and around Narssaq, where skarns and sillimanitecordierite gneisses occur. As McGregor recognised, this association suggests a supracrustal origin for the amphibolites. Olivine-bearing ultrabasic rocks are associated with the amphibolites and may be derived from olivine-rich lavas forming part of the basaltic volcanism which was parent to the amphibolite formations. Contacts of both amphibolitic and ultrabasic formations with surrounding gneisses appear for the most part to be tectonic or agmatitic.

Anorthosite formations which have been mapped north of Buksefjorden, and between Færingehavn and Tre Brødre, may be part of one major intrusion. They range from true anorthosites to gabbroic rocks rich in amphibole. Phase or rhythmic layering is well preserved in spite of subsequent folding and the superimposition of penetrative tectonic fabrics. They are generally bordered by amphibolite and contain hornblende-rich xenoliths, which suggest that the anorthosites may be younger than the amphibolites. However the possibility that anorthosites were formed at different times cannot be ruled out as anorthosite clots occur in the Ameralik dykes. In many instances the anorthosites are cut by pegmatitic veins and sheets of granodiorite which resemble the Nûk gneisses.

Flat-lying sheets of weakly-foliated granite, locally aplitic or pegmatitic, cut across folds in the gneisses in the north of the map sheet. They are younger than the Nûk gneisses and are genetically and structurally related to vertical north-easttrending pegmatite sheets which are prominent north of Buksefjorden and around Færingehavn, both being associated with regional arching.

All these rocks are cut by swarms of dolerite dykes which were emplaced in cool brittle crust. Marginal chills or tachylite development are ubiquitous and en echelon relations common. They are of two sets; the oldest trending $080^{\circ}$ and the youngest $100^{\circ}$ to $110^{\circ}$.

\section{Structure}

The structural history is complex but a provisional regional chronology has been established. There have been at least six stages of ductile deformation with constrictional strains prominent in at least two, associated with regional metamorphism of high grade. Where the Ameralik dykes are little deformed two sets of older small-scale isoclinal intrafolial folds can be seen, with the main gneiss banding being developed with the second set. The Ameralik dykes are locally boudinaged with an associated faint mineral rodding. In most areas, however, the dykes are intensely deformed and little can be seen of the pre-dyke history. The basic dykes themselves may have been intruded in two periods, the older ones being boudinaged before the emplacement of the second.

There is no evidence of deformation and metamorphism between the deposition of the Malene supracrustals and the emplacement of the anorthosites, nor between the anorthosites and the generation of the pre-Nûk nebulitic gneisses. South of Færingehavn, the 'stratigraphy' recognisable in the anorthosite sheets 


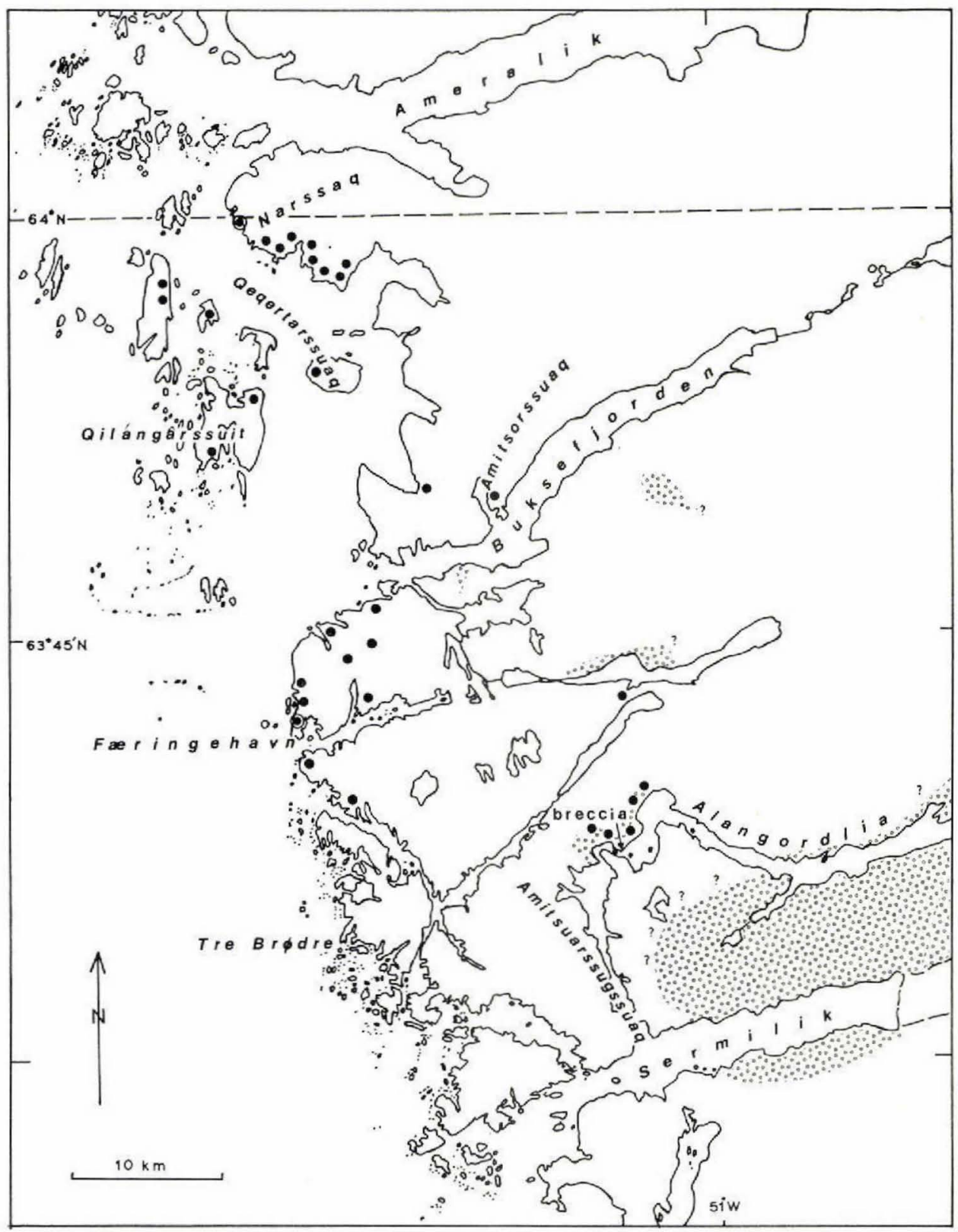

Fig. 4. Map of the Buksefjorden region, West Greenland showing the localities mentioned in the article by Chadwick \& Coe. The dashed line, $64^{\circ} \mathrm{N}$, marks the northern limit of the map area; Sermilik forms the southern boundary. Areas containing metamorphosed basic dykes are indicated by full circles and areas of granulite-facies metamorphism are shown by small-circle ornament. 
shows that they have been folded into large-scale isoclines during a period of major metamorphism. A penetrative planar fabric developed parallel to fold axial surfaces in the anorthosites, amphibolites and other lithologies. Pegmatites also formed syntectonically. Constrictional deformation marked the close of this event with the development of a conspicuous quartz rodding in the Færingehavn area. Large-scale asymmetric folding followed this, again accompanied by metamorphism and anatexis. New axial surface fabrics were generated, together with a widely-developed mineral lineation parallel to fold axes which for the most part plunge gently south or south-west.

These major tectonic events were followed by the emplacement of the sheets of granite, pegmatite and aplite mentioned earlier, some of which reveal minor deformation with folds having horizontal axial surfaces and local axial surface fabrics. Regional dome and basin buckling of varying intensity terminated the folding episodes.

\section{Metamorphism}

Metamorphism older than the Nûk gneisses was generally of upper amphibolite to granulite facies and was associated with the isoclinal folding of anothosites. A second metamorphism in granulite facies occurred during deformation which followed the intrusion of the Nûk gneisses. There are three lines of evidence for this. Firstly, the occurrence of hypersthene aligned parallel to the southerly plunging fold axes of folds which deform the Nûk gneisses in Sermilik. Secondly, in parts of Alangordlia rafts of granulite-facies Amîtsoq gneisses with Ameralik dykes occur in Nûk gneisses of lower grade whilst to the south and east the Nûk gneisses are themselves in granulite facies. Thirdly, on the north shore of Alangordlia (fig. 4) a breccia of probable sedimentary origin contains disoriented fragments of granulite-facies gneiss in an amphibolite matrix. The breccia is penetrated by granitic veins continuous with the host rock which itself is of granulite facies.

\section{References}

Berthelsen, A. 1955: Structural studies in the pre-Cambrian of Western Greenland. I. A small body of diorite, Godthaab District. Bull. Grønlands geol. Unders. 10, (also Meddr Grønland 135, 6), 29 pp.

McGregor, V. R. 1973: The early Precambrian gneisses of the Godthåb district, West Greenland. Phil. Trans. R. Soc. Lond. A, 273, 343-358.

Noe-Nygaard, A. \& Ramberg, H. 1961: Geological reconnaissance map of the country between latitudes $69^{\circ} \mathrm{N}$ and $63^{\circ} 45^{\prime} \mathrm{N}$, West Greenland. Map Grønlands geol. Unders. 1 (also Meddr Grønland 123, 5).

Oxford Isotope Geology Laboratory \& McGregor, V. R. 1971: Isotopic dating of very early Precambrian amphibolite facies gneisses from the Godthaab district, West Greenland. Earth Planet. Sci. Lett. 12, 245-259.

Sørensen, H. 1955: Anorthosite from Buksefjorden, West Greenland. Meddr dansk geol. Foren. 13, 31-41. 
Windley, B. F. 1972: Regional geology of early Precambrian high-grade metamorphic rocks in West Greenland. Part 1: Kângnaitsoq to Ameralik. Rapp. Grønlands geol. Unders. 46, $46 \mathrm{pp}$.

Department of Geology, The University, Exeter, Devonshire, England.

\section{REGIONAL MAPPING OF THE PRECAMBRIAN BASEMENT IN THE FISKEN $\approx$ ESSET REGION, SOUTHERN WEST GREENLAND}

\section{Feiko Kalsbeek}

The systematic mapping of the Fiskenæsset region which began in 1970 (see previous GGU Reports of Activities) was continued in the period June to September. Apart from the author the following geologists took part: C. R. L. Friend (Portsmouth Coll. of Tech.), A. M. Hopgood (Univ. of St. Andrews), D. K. Hutt (Univ. of London), J. S. Myers (GGU), G. A. G. Nunn (Univ. of Liverpool), R. P. E. Poorter (Univ. of Utrecht), T. C. R. Pulvertaft (Univ. of Copenhagen), J. Tonika (Geol. Surv. Prague) and B. F. Windley (Univ. of Leicester). R. K. Herd (Carleton Univ., Ottawa) continued the study of the sapphirine-bearing rocks of the area begun in 1970 and W. F. Fahrig (Geol. Surv. of Canada) visited the area for a shorter period to sample basic dykes for palaeomagnetic and isotopic studies.

The two-man field parties were served by two helicopters and the GGU motor cutters "J. F. Johnstrup" and "Villiaumit" operating from the base-camp Midgaard. As in previous years Ib Olsen (GGU) took care of most of the practical arrangements.

Mapping in most of the area south of Fiskenæsfjorden (between $62^{\circ} 40^{\prime} \mathrm{N}$ and $63^{\circ} 00^{\prime} \mathrm{N}$ ) has now been finished and mapping in the region between Fiskenæsfjorden and Grædefjord $\left(63^{\circ} 20^{\prime} \mathrm{N}\right)$ is in progress.

No essentially new developments in the understanding of the geology of the area have resulted from this summer's field work, but with the help of the mapping, especially of the anorthosite complexes, the complex structural style of the area gradually becomes clearer. Well-preserved igneous structures have again been found at several localities in the anorthosites and associated rocks of the Fiskenæsset complex. Granitic augen gneisses, which cut earlier migmatites but are themselves cut be younger granite material, become more common towards Grædefjord.

For details of the bedrock geology of the Fiskenæsset area, the reader is referred to Rapp. Gronlands geol. Unders. 51, 1973, in which papers dealing with different aspects of the regional mapping have been assembled. 